\title{
Novel dihydrobenzofuro[4,5-b][1,8]naphthyridin-6-one derivative, MHY-449, induces apoptosis and cell cycle arrest in HCT116 human colon cancer cells
}

\author{
HYE JUNG HWANG*, YONG JUNG KANG* ${ }^{*}$, MOHAMMAD AKBAR HOSSAIN, DONG HWAN KIM, \\ JUNG YOON JANG, SUN HWA LEE, JEONG-HYUN YOON, HYUNG RYONG MOON, \\ HYUNG SIK KIM, HAE YOUNG CHUNG and NAM DEUK KIM
}

\begin{abstract}
Division of Pharmacy, College of Pharmacy, Molecular Inflammation Research Center for Aging
Intervention (MRCA), Pusan National University, Busan 609-735, Republic of Korea
\end{abstract}

Received July 7, 2012; Accepted August 6, 2012

DOI: 10.3892/ijo.2012.1659

\begin{abstract}
Colorectal cancer (CRC) is the second most frequent cancer in men and the third most common cancer in women in Korea. In spite of the significant advances in conventional therapeutic approaches to CRC, most patients ultimately die of their disease. There is a need to develop novel preventive approaches for this malignancy. This study was carried out to investigate the anticancer effect of the diastereoisomeric compounds, MHY-449 and MHY-450, novel dihydrobenzofuro[4,5-b] $[1,8]$ naphthyridin-6-one derivatives, on HCT116 human colon cancer cells. MHY-449 exhibited more potent cytotoxicity than MHY-450, against HCT116 cells. Treatment of cells with MHY-449 resulted in growth inhibition and induction of apoptosis in a concentration-dependent manner, and inhibition of proliferation in a time-dependent manner. The induction of apoptosis was observed by decreased cell viability, DNA fragmentation, activation of protein levels involved in death receptors. Moreover, activation of caspase- $3,-8$ and -9 and cleavage of poly(ADP-ribose) polymerase and alteration in the ratio of Bax/Bcl-2 protein expression was observed. MHY-449 induced $\mathrm{G} 2 / \mathrm{M}$ phase arrest in the cell cycle progression which was observed by flow cytometry analysis, and a decrease in the protein expression of cyclin B1 and its activating partners $\mathrm{Cdc} 25 \mathrm{c}$ and Cdc2. MHY-449 also caused increase in the expression levels of $\mathrm{p} 53$, a tumor suppressor gene, and p21 WAFI/CIP and $\mathrm{p} 27^{K I P}, \mathrm{G} 2 / \mathrm{M}$ phase inhibitors. These results suggest that MHY-449 may be a useful candidate for chemo-prevention and/or treatment of colon cancer.
\end{abstract}

Correspondence to: Dr Nam Deuk Kim, Department of Pharmacy, College of Pharmacy, Pusan National University, Busan 609-735, Republic of Korea

E-mail: nadkim@pusan.ac.kr

${ }^{*}$ Contributed equally

Key words: dihydrobenzofuro[4,5-b][1,8]naphthyridin-6-one derivatives, cytotoxic activity, colon cancer cells, apoptosis, cell cycle regulation

\section{Introduction}

Colorectal cancer (CRC) is a malignant neoplasm arising from the lining of the large intestine (colon and rectum) (1). CRC is the third most common cancer and the third leading cause of cancer-related death in the United States (2). The incidence of CRC in Korea has increased significantly over the past few decades. According to the National Cancer Registry of Korea, age-standardized incidence rates increased from 27.0 to 50.2 per 100,000 for men and from 17.1 to 26.9 per 100,000 for women between 1999 and 2009. The overall incidence of CRC increased by $6.7 \%$ annually in men and $5.1 \%$ in women from 1999 to 2009 , while the incidence rates of the most common cancers, such as stomach and liver cancer, decreased during the same period (3). While more than $50 \%$ of CRC patients with surgical resection is cured, $40-50 \%$ of these subjects eventually experience recurrences and the possibility of re-operation is very low (4). Because of incomplete therapeutic options for $\mathrm{CRC}$, there is a need to develop novel preventive treatment approaches for this malignancy.

Apoptosis, a controlled and energy-dependent process, is the best-described form of programmed cell death. There are two major apoptotic pathways, which are the extrinsic pathway and the intrinsic pathway (5). The extrinsic pathway is initiated by the binding of transmembrane death receptors [Fas, tumor necrosis factor receptor 1 (TNFR1), TNF-related apoptosis-inducing ligand (TRAIL) receptors] with cognate extracellular ligands (6). Ligand receptors recruit adaptor proteins [TNFR-associated death domain (TRADD) and Fas-associated death domain (FADD)], which interact with and trigger the activation of caspase- 8 . Activated caspase- 8 thereby stimulates the effector caspases-3, -6 and -7 which ultimately execute apoptosis (7). TNF- $\alpha$ is known to trigger apoptotic death via TNFR1 (8). The intrinsic pathway is dominated by the $\mathrm{Bcl}-2$ family of proteins which govern the release of cytochrome $c$ from the mitochondria $(9,10)$. Cytochrome $c$ stimulates the formation of apoptosome (Apaf-1, dATP, cytochrome $c$ and caspase-9) followed by activation of caspase-9, which in turn causes the activation of the 'executioner' caspases $(-3,-6$ and -7$)(9,11,12)$. 
Psorospermin, a natural product isolated from the tropical plant Psorospermum febrifugum, consists of a xanthone scaffold and was reported to exhibit potent anticancer activity in vitro and in vivo $(13,14)$. Acronycine, an alkaloid first isolated from Acronychia baueri Schott (Rutaceae) consists of an acridone scaffold and showed a broad spectrum of activity against a variety of solid tumors including sarcoma, myeloma, carcinoma, and melanoma (15). On the basis of the chemical structures of psorospermin with a xanthone template and acronycine derivatives with an acridone template, MHY-449 and MHY-450 (Fig. 1A) constructed on a 1,2-dihydrobenzofuro [4,5-b][1,8]naphthyridin-6(11H)-one scaffold were designed and synthesized as potential anticancer agents (16). Their cytotoxicities were evaluated against five human cancer cell lines, such as prostate cancer cell lines (LNCap, DU145 and PC3) and breast cancer cell lines (MCF-7/ADR and MCF-7). MHY-449 and MHY-450 have shown cytotoxicity against human prostate and breast cancer cells and induction of G2/M phase arrest of the cell cycle in MCF-7/ADR cells, however, the underlying molecular mechanisms of these cytotoxic effects and G2/M phase arrest were not fully elucidated. Therefore, the current study was designed to investigate the effects on HCT116 human colon cancer cells and its mechanisms by which these novel derivatives induce apoptosis and modulation of the cell cycle in HCT116 human colon cancer cells.

\section{Materials and methods}

Chemicals. The simplified code names and structures of MHY-449 $\left[( \pm)-\left(\mathrm{R}^{*}\right)-5\right.$-methoxy-11-methyl-2-(( $\left.\mathrm{R}^{*}\right)-2$-methyloxiran-2-yl)-1,2dihydrobenzofuro[4,5-b][1,8]naphthyridin-6(11H)-one] and MHY-450 [( \pm$)-\left(\mathrm{R}^{*}\right)-5$-methoxy-11-methyl-2-((S*)-2-methyloxiran2-yl)-1,2-dihydrobenzofuro[4,5-b][1,8]naphthyridin-6(11H)-one] used in this study are shown in Fig. 1. Detailed methods for the design and synthesis of these compounds are described elsewhere (16). They were dissolved in dimethylsulfoxide (DMSO) and stored at $-20^{\circ} \mathrm{C}$ before the experiments and dilutions were made in culture medium. The maximal concentration of DMSO did not exceed $0.1 \%(\mathrm{v} / \mathrm{v})$ in the treatment range of $0.125-0.5 \mu \mathrm{M}$, where there was no influence on the cell growth.

Cell culture and growth study. The human colon cancer HCT116 cells were cultured in RPMI-1640 (Hyclone, Logan, UT, USA) supplemented with $10 \%$ fetal bovine serum (FBS, Hyclone), 2 mM glutamine (Sigma-Aldrich Co., St. Louis, MO, USA), $100 \mathrm{U} / \mathrm{ml}$ penicillin (Hyclone) and $100 \mu \mathrm{g} / \mathrm{ml}$ streptomycin (Hyclone) at $37^{\circ} \mathrm{C}$ in a humidified $5 \% \mathrm{CO}_{2}$. Cell viability was determined by MTT assay and by trypan blue staining assay. For the MTT assay, HCT116 cells were seeded in a 24 -well culture plate at a density of $4 \times 10^{4}$ cells/well, cultured for $24 \mathrm{~h}$ in the growth media and then treated with or without various reagents for the indicated concentrations. The cells were incubated with $0.5 \mathrm{mg} / \mathrm{ml}$ MTT [3-(4,5-dimethylthiazol-2-yl)2,5-diphenyltetrazolium bromide] (Sigma-Aldrich) at $37^{\circ} \mathrm{C}$ for $2 \mathrm{~h}$. The formazan granules generated by the live cells were dissolved in DMSO and the absorbance at $540 \mathrm{~nm}$ was monitored by using a multi-well reader. For the trypan blue staining assay, the reagents-treated HCT116 cells were harvested by trypsinization, suspended in phosphate-buffered saline (PBS), stained by trypan blue stain (Gibco, Rockville, MD, USA) solution and the number of viable cells was counted using a hemacytometer.

Nuclear staining with Hoechst 33342. Cells were washed with PBS and fixed with $3.7 \%$ paraformaldehyde (Sigma-Aldrich) in PBS for $10 \mathrm{~min}$ at room temperature. Fixed cells were washed with PBS and stained with $4 \mu \mathrm{g} / \mathrm{ml}$ Hoechst 33342 for $20 \mathrm{~min}$ at room temperature. The cells were washed two more times with PBS and analyzed by a fluorescent microscope.

Assessment of DNA degradation. Cells were lysed in a buffer, containing $5 \mathrm{mM}$ Tris- $\mathrm{HCl}(\mathrm{pH} 7.5), 5 \mathrm{mM}$ EDTA, and $0.5 \%$ Triton $\mathrm{X}-100$, for $30 \mathrm{~min}$ on ice. Lysates were vortexed and cleared by centrifugation at $27,000 \mathrm{x} \mathrm{g}$ for $20 \mathrm{~min}$. Fragmented DNA in the supernatant was treated with RNase, followed by proteinase $\mathrm{K}$ digestion, phenol/chloroform/isoamyl alcohol mixture (25:24:1, v/v/v) extraction and isopropanol precipitation. DNA was separated through a $1.5 \%$ agarose gel, was stained with $0.1 \mu \mathrm{g} / \mathrm{ml}$ ethidium bromide (EtBr) and was visualized by UV source.

Cell cycle analysis. The DNA content was measured following the staining of the cells with propidium iodide (PI, Sigma-Aldrich). The cells were treated under the appropriate conditions for $24 \mathrm{~h}$, subsequently trypsinized, washed once in cold PBS and then fixed in $70 \%$ ethanol at $4^{\circ} \mathrm{C}$ overnight. The fixed cells were pelleted and stained in cold PI solution (50 $\mu \mathrm{g} / \mathrm{ml}$ in PBS) at room temperature for $30 \mathrm{~min}$ in the dark. Flow cytometry analysis was performed on a FACScan flow cytometry system (Becton-Dickinson, San Jose, CA, USA).

Caspase activity assay. The cells were harvested and washed with cold PBS. Total cells were lysed with the lysis buffer [40 mM Tris (pH 8.0), $120 \mathrm{mM}, \mathrm{NaCl}, 0.5 \%$ NP-40, $0.1 \mathrm{mM}$ sodium orthovanadate, $2 \mu \mathrm{g} / \mathrm{ml}$ aprotinin, $2 \mu \mathrm{g} / \mathrm{ml}$ leupeptin and $100 \mu \mathrm{g} / \mathrm{ml}$ phenymethylsulfonyl fluoride (PMSF)] at $4^{\circ} \mathrm{C}$ for $30 \mathrm{~min}$. The lysed cells were centrifuged at $14,000 \mathrm{rpm}$ for $10 \mathrm{~min}$ and $100 \mu \mathrm{g}$ protein was incubated with $100 \mu \mathrm{l}$ of reaction buffer and $10 \mu \mathrm{l}$ of colorimetric tetrapeptides, Z-DEVDpNA for caspase-3, Z-IETD-pNA for caspase-8, and Ac-LEHD-pNA for caspase-9, respectively. The reaction mixture was incubated at $37^{\circ} \mathrm{C}$ for $30 \mathrm{~min}$ and liberated p-nitroaniline (pNA) was measured at $405 \mathrm{~nm}$ using a multi-well reader.

Annexin V staining. Annexin V-FITC is used to quantitatively determine the percentage of cells within a population that are actively undergoing apoptosis. The cells were treated under the appropriate conditions for $24 \mathrm{~h}$, subsequently harvested, trypsinized, washed once in cold PBS, suspended the cells in $1 \mathrm{X}$ binding buffer (Becton-Dickinson, Annexin V-FITC Apoptosis Detection kit). The counted cells were stained in PI and Annexin V-FITC solution (Becton-Dickinson, Annexin V-FITC Apoptosis Detection Kit) at room temperature for $15 \mathrm{~min}$ in the dark. The stained cells were analyzed by flow cytometry within $1 \mathrm{~h}$.

Western blot analysis. The cells were treated under the appropriate conditions, harvested and washed with cold PBS. Total cells were lysed in lysis buffer [40 mM Tris (pH 8.0), $120 \mathrm{mM}$ $\mathrm{NaCl}, 0.5 \% \mathrm{NP}-40,0.1 \mathrm{mM}$ sodium orthovanadate, $2 \mu \mathrm{g} / \mathrm{ml}$ 
Table I. Primary antibodies used in western blot analysis.

\begin{tabular}{llll}
\hline Antibody & 2nd antibody & Dilution ratio & Company \\
\hline Fas & Rabbit & $1: 1,000$ & Santa Cruz \\
Fas-L & Rabbit & $1: 500$ & Santa Cruz \\
TRAIL & Rabbit & $1: 1,000$ & Santa Cruz \\
DR4 & Rabbit & $1: 1,000$ & Santa Cruz \\
DR5 & Mouse & $1: 1,000$ & Santa Cruz \\
Bax & Rabbit & $1: 1,000$ & Santa Cruz \\
Bcl-2 & Mouse & $1: 500$ & Santa Cruz \\
Cdc2 & Rabbit & $1: 1,000$ & Santa Cruz \\
Cdc25c & Rabbit & $1: 1,000$ & Santa Cruz \\
Cyclin B1 & Mouse & $1: 1,000$ & Santa Cruz \\
Wee1 & Mouse & $1: 500$ & Santa Cruz \\
p21 & Mouse & $1: 1,000$ & Santa Cruz \\
p27 & Mouse & $1: 1,000$ & Santa Cruz \\
p53 & Mouse & $1: 1,000$ & Santa Cruz \\
PARP & Mouse & $1: 1,000$ & Santa Cruz \\
Procaspase-3 & Mouse & $1: 1,000$ & Santa Cruz \\
Procaspase-8 & Rabbit & $1: 500$ & Santa Cruz \\
Procaspase-9 & Rabbit & $1: 500$ & Santa Cruz \\
$\beta$-actin & Mouse & $1: 10,000$ & Sigma-Aldrich \\
\hline
\end{tabular}

aprotinin, $2 \mu \mathrm{g} / \mathrm{ml}$ leupeptin and $100 \mu \mathrm{g} / \mathrm{ml}$ phenymethylsulfonyl fluoride (PMSF)]. The supernatant was collected and protein concentrations were then measured with protein assay reagents (Pierce, Rockford, IL, USA). Protein extracts were denatured by boiling at $100^{\circ} \mathrm{C}$ for $5 \mathrm{~min}$ in sample buffer $(0.5 \mathrm{M}$ Tris $-\mathrm{HCl}$, $\mathrm{pH}$ 6.8, 4\% SDS, $20 \%$ glycerol, $0.1 \%$ bromophenol blue, $10 \% \beta$-mercaptoethanol). Equal amount of the total proteins were subjected to $6-15 \%$ SDS-PAGE and transferred to PVDF. The membranes were blocked with $5 \%$ non-fat dry milk in Tris-buffered saline with Tween-20 buffer (TBS-T) $(20 \mathrm{mM}$ Tris, $100 \mathrm{mM} \mathrm{NaCl}, \mathrm{pH} 7.5$ and $0.1 \%$ Tween-20) for $1 \mathrm{~h}$ at room temperature. Then, the membranes were incubated for overnight at $4^{\circ} \mathrm{C}$ with the primary antibodies (Table I). The membranes were washed once for 10 min with $4 \mathrm{X}$ TBS-T buffer and incubated for $1 \mathrm{~h}$ with horseradish peroxidase-conjugated anti-rabbit or anti-mouse immunoglobin (Santa Cruz Biotechnology Inc., Santa Cruz, CA, USA). The membranes were washed again for 10 min with 4X TBS-T buffer. Antigen-antibody complexes were detected by the enhanced chemiluminescence (ECL) detection system (Amersham Biosciences Co., Little Chalfont, UK).

Statistical analysis. Results were expressed as the mean \pm SD of three separate experiments and analyzed by Student's t-test. Means were considered significantly different at * $\mathrm{p}<0.05$ or ${ }^{* *} \mathrm{p}<0.01$.

\section{Results}

MHY-449 exhibits more potent cytotoxicity than MHY-450 against HCT116 cells. To investigate the effects of MHY-449 and MHY-450 (Fig. 1A), the diastereoisomeric compounds, on the viability of HCT116 cells, the MTT assay was performed. As shown in Fig. 1B, both MHY-449 and MHY-450 showed
A
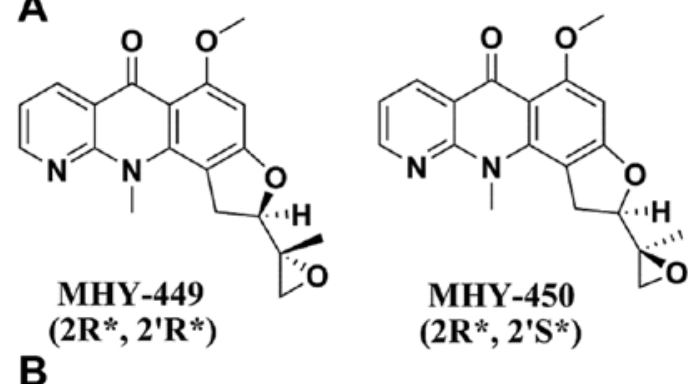

$\left(2 \mathbf{R}^{*}, \mathbf{2}^{\prime} \mathrm{S}^{*}\right)$

B

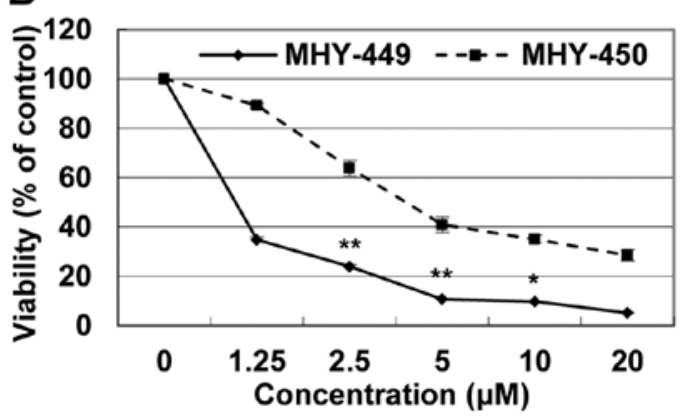

Figure 1. Chemical structures and effects of MHY-449 and MHY-450 on the viability of HCT116 cells. (A) MHY-449 [( \pm )-(R*)-5-methoxy-11-methyl-2-(( $\left.\mathrm{R}^{*}\right)$ 2-methyloxiran-2-yl)-1,2-dihydrobenzofuro[4,5-b][1,8]naphthyridin-6(11H)-one] and MHY-450 [( \pm )-( $\left.\mathrm{R}^{*}\right)-5$-methoxy-11-methyl-2-(( $\left.\mathrm{S}^{*}\right)-2$-methyloxiran-2-yl)-1,2dihydrobenzofuro[4,5-b][1,8]naphthyridin-6(11H)-one.(B) One day after seeding, HCT116 cells were treated with incremental concentration of MHY-449 and MHY-450 for $24 \mathrm{~h}$. Proliferation was measured by using the MTT assay. Results are expressed as mean $\pm \mathrm{SD}(\mathrm{n}=6)$. ${ }^{*} \mathrm{p}<0.05$ and ${ }^{* *} \mathrm{p}<0.01$ compared between MHY-449 and MHY-450 treated cells.

concentration-dependent cytotoxicity on HCT116 cells. MHY-449, however, exhibited more potent cytotoxicity than MHY-450. Therefore, further experiments were performed only with MHY-449.

MHY-449 inhibits the growth of HCT116 cells. MHY449 showed concentration-dependent cytotoxicity on HCT116 cells. The $\mathrm{IC}_{50}$ value of MHY-449 on HCT116 cells was approximately $0.5 \mu \mathrm{M}$ (Fig. 2A). Following experiment was performed in order to investigate whether MHY-449 has an anti-proliferation effect on HCT116 cells by using the trypan blue staining assay. As shown in Fig. 2B, MHY-449 showed time-dependent anti-proliferation effect on HCT116 cells.

MHY-449 induces apoptosis in HCT116 cells. To investigate whether the growth inhibitory effects of MHY-449 were due to the induction of apoptosis in HCT116 cells, microphotographs were observed. HCT116 cells treated with MHY-449 showed distinct morphological changes compared with control (Fig. 3A upper panel). They were rounded and more dispersed with aggregation in a concentration-dependent manner. Further morphological changes of cellular structures were assessed with Hoechst 33342 staining. As shown in Fig. 3A lower panel, nuclei with chromatin condensation and formation of apoptotic bodies, which are characteristics of apoptosis, were seen in cells cultured with MHY-449 in a concentration-dependent manner, whereas the control cells maintained nuclear structure intact. In addition to this, to confirm the apoptosis of MHY-449 in the HCT116 cells, 

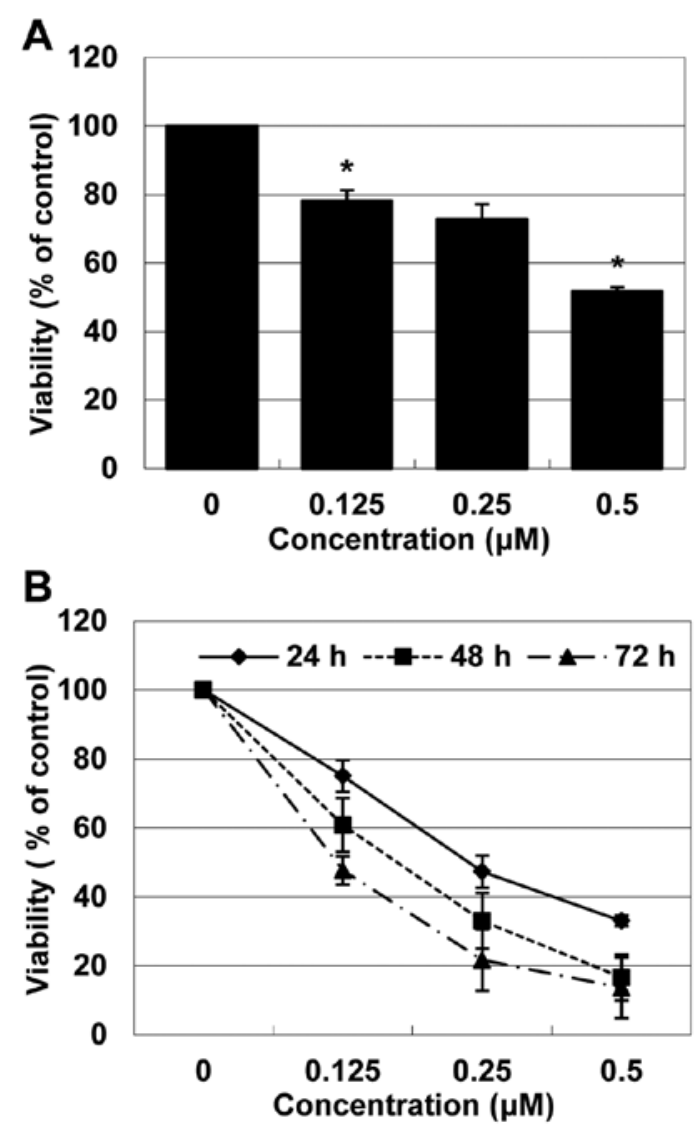

Figure 2. Concentration- and time-dependent effects of MHY-449 on the viability of HCT116 cells. (A) One day after seeding, HCT116 cells were treated with incremental concentration of MHY-449 for $24 \mathrm{~h}$. Proliferation was measured by using the MTT assay. The results are expressed as mean $\pm \mathrm{SD}(\mathrm{n}=6)$ and as a percentage of vehicle-treated control. ${ }^{*} \mathrm{p}<0.05$ compared between vehicle-treated control and MHY-449 treated cells. (B) To study anti-proliferative effects of MHY-449 on HCT116 cells, cells were treated with incremental concentration of MHY-449 for 24, 48 and $72 \mathrm{~h}$. Proliferation was measured by using the trypan blue staining assay. The results are expressed as mean $\pm S D(n=3)$ and as a percentage of vehicletreated control.

flow cytometry analysis and DNA fragmentation assay were performed. As shown in Fig. 3B, increases of early apoptosis (lower right quadrant) and late apoptosis/death (upper right quadrant) were clearly observed in concentration-dependent manner. We also analyzed whether DNA fragmentation, another hallmark of apoptosis, was induced by MHY-449 treatment on HCT116 cells. Following agarose gel electrophoresis of HCT116 cells treated with MHY-449 for $24 \mathrm{~h}$, a typical ladder pattern of internucleosomal fragmentation was observed in a concentration-dependent manner (Fig. 3C).

MHY-449 upregulates the expression of apoptosis-related proteins in the extrinsic pathway. The extrinsic pathway of apoptosis in which Fas/FasL system plays a key signaling transduction has been proposed as a therapeutic target in cancer. Thus, involvement of the Fas/FasL system in HCT116 cells treated with MHY-449 was examined. As shown in Fig. 4, the levels of Fas as well as FasL expression were significantly up-reregulated in a concentration-dependent manner. However, the levels of tumor necrosis factor (TNF)-

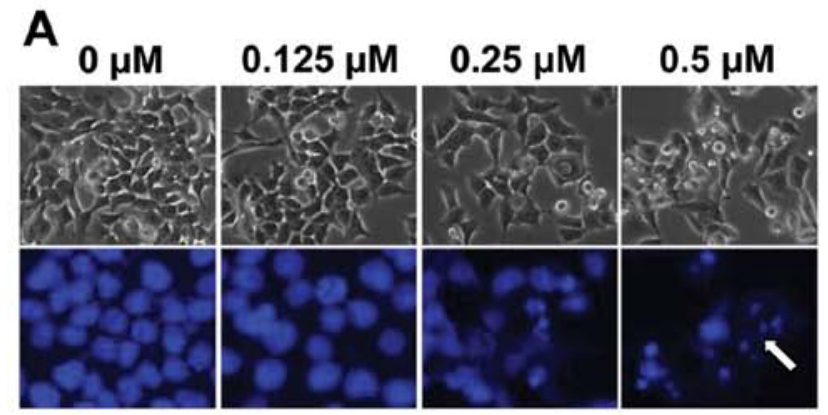

B

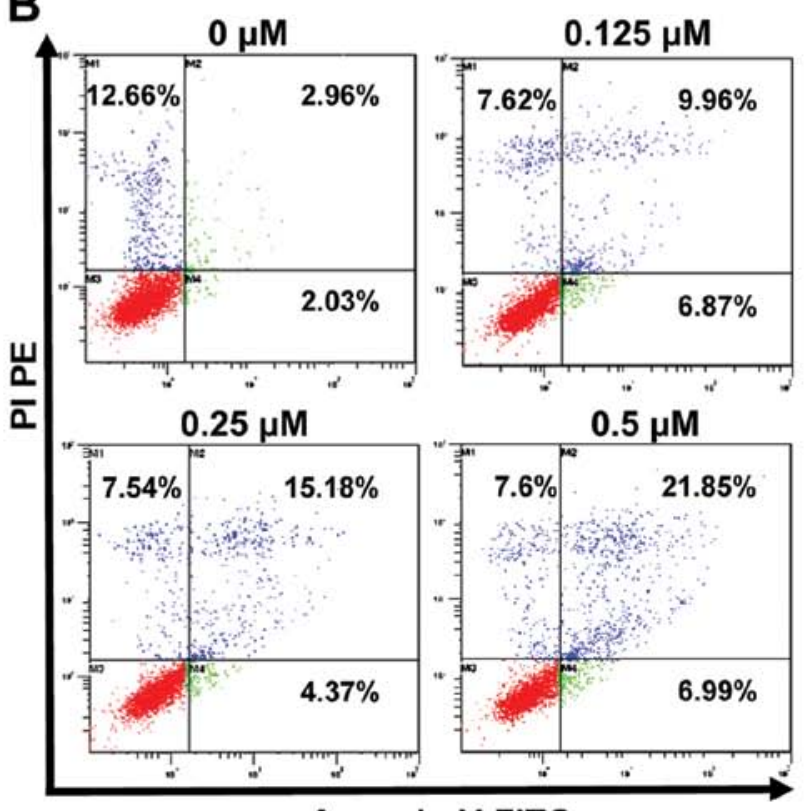

Annexin-V FITC
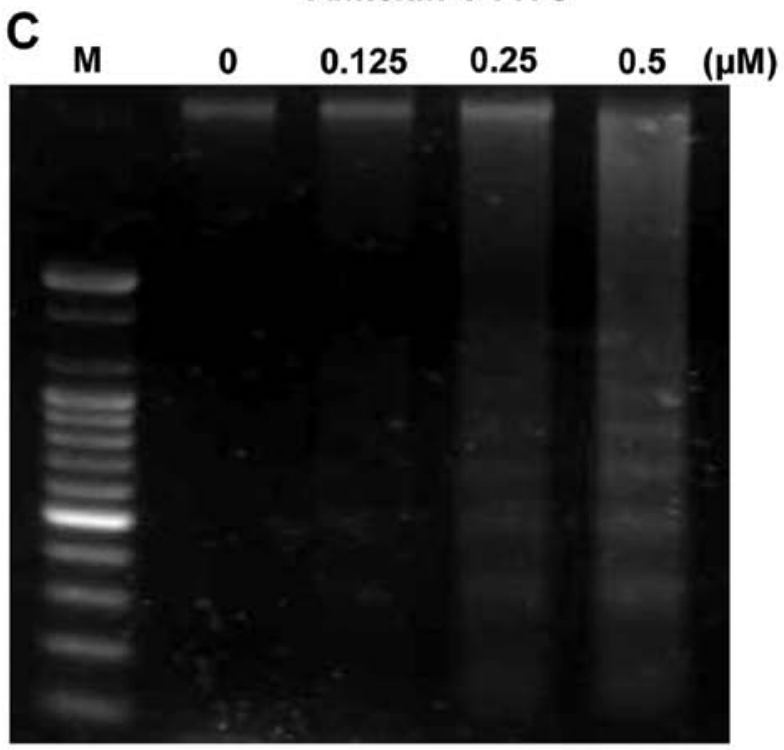

Figure 3. Induction of apoptosis in HCT116 cells by MHY-449. (A) HCT116 cells were treated for $24 \mathrm{~h}$ with the indicated concentrations of MHY-449 and morphological changes were observed by phase contrast microscopy at $\mathrm{x} 400$ magnification (upper panel). Stained nuclei with fluorescent DNA-binding dye, Hoechst 33342, were then photographed with a fluorescent microscope using a blue filter at $\mathrm{x} 400$ magnification (upper panel). Apoptotic cells (arrow). (B) To investigate the effect of MHY-449 on cell death, HCT116 cells were treated for $24 \mathrm{~h}$ with the indicated concentrations of MHY-449. Annexin V binding and PI uptake in non-permeabilized cells and analyzed with a flow cytometry. (C) To analyze fragmentation of genomic DNA, cells were treated for $24 \mathrm{~h}$ with the indicated concentrations of MHY-449. DNA was extracted and analyzed by $1 \%$ agarose gel electrophoresis in the presence of EtBr. A representative blot is shown from three independent experiments. M, marker. 


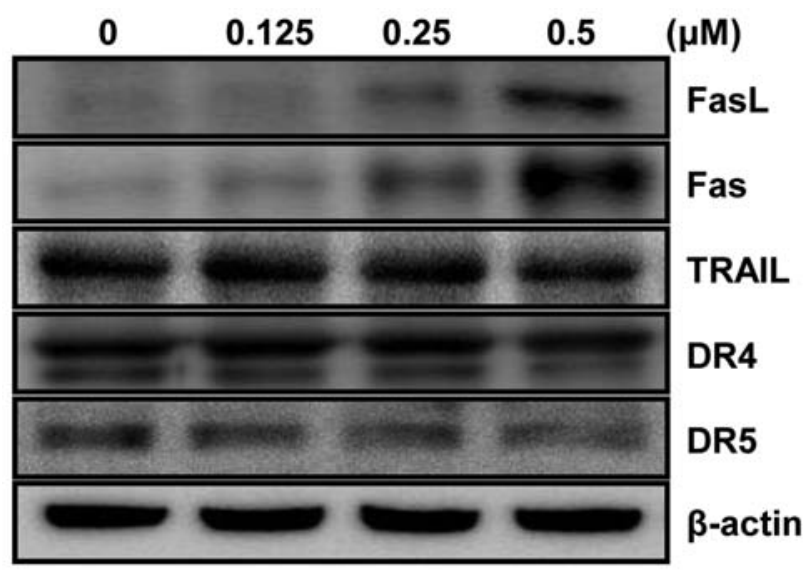

Figure 4. Effect of MHY-449 on the expression levels of proteins involved in extrinsic and intrinsic pathways of apoptosis in HCT116 cells. HCT116 cells were treated for $24 \mathrm{~h}$ with the indicated concentrations of MHY-449. The expression levels of proteins involved in extrinsic pathway, such as FasL, Fas, TRAIL, DR4 and DR5 in HCT116 cells were detected by western blot analysis. Proteins were visualized using the ECL detection system. Representative results from three independent experiments are shown. Actin was used as a loading control.
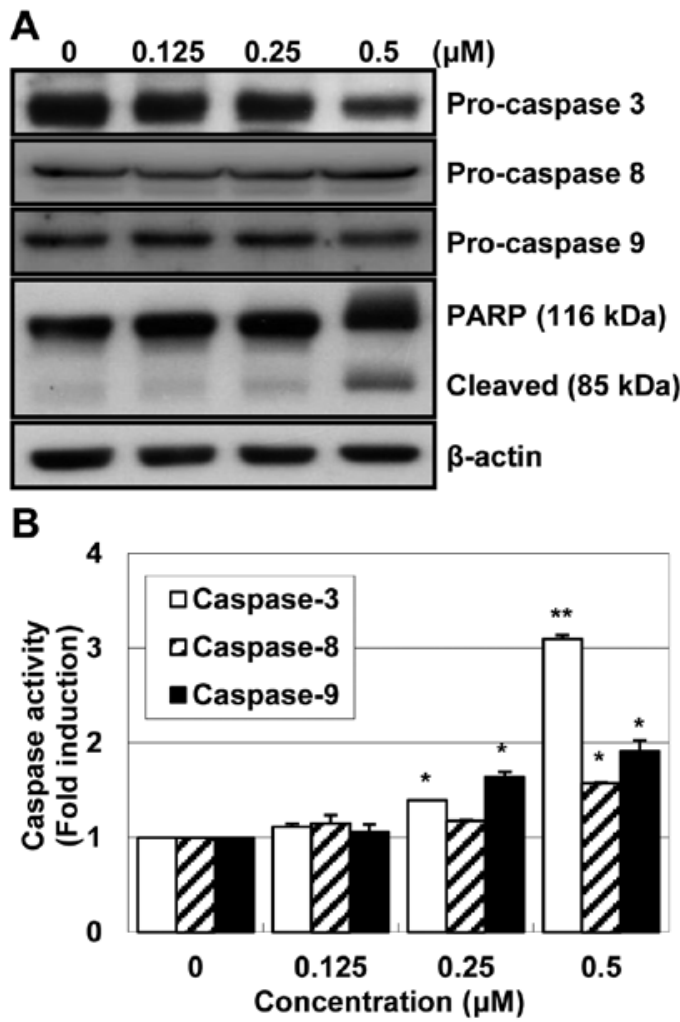

Figure 5. Effect of MHY-449 on activation of caspase-3, -8 , and -9 and degradation of PARP in HCT116 cells. (A) HCT116 cells were treated with indicated concentrations of MHY-449 for $24 \mathrm{~h}$, collected, lysed and then cellular proteins were separated and immunoblotted. The membranes were probed with procaspase-3, pro-caspase-8, procaspase-9 and PARP (116 kDa). Proteins were visualized using the ECL detection system. Representative results from three independent experiments are shown. Actin was used as a loading control. (B) To detect caspase activities, cell lysates from cells treated with MHY-449 for $24 \mathrm{~h}$ were assayed for in vitro caspase-3, -8 and -9 activity using Z-DEVD-pNA, Z-IETD-pNA and Ac-LEHD-pNA, respectively, as substrates at $37^{\circ} \mathrm{C}$ for $1 \mathrm{~h}$. The released fluorescent products were measured. The data represent the mean \pm SD values of three independent experiments. The significance was determined by Student's t-test ( $\mathrm{p}<0.05$ and ${ }^{* *} \mathrm{p}<0.01$ vs. vehicle-treated control cells).
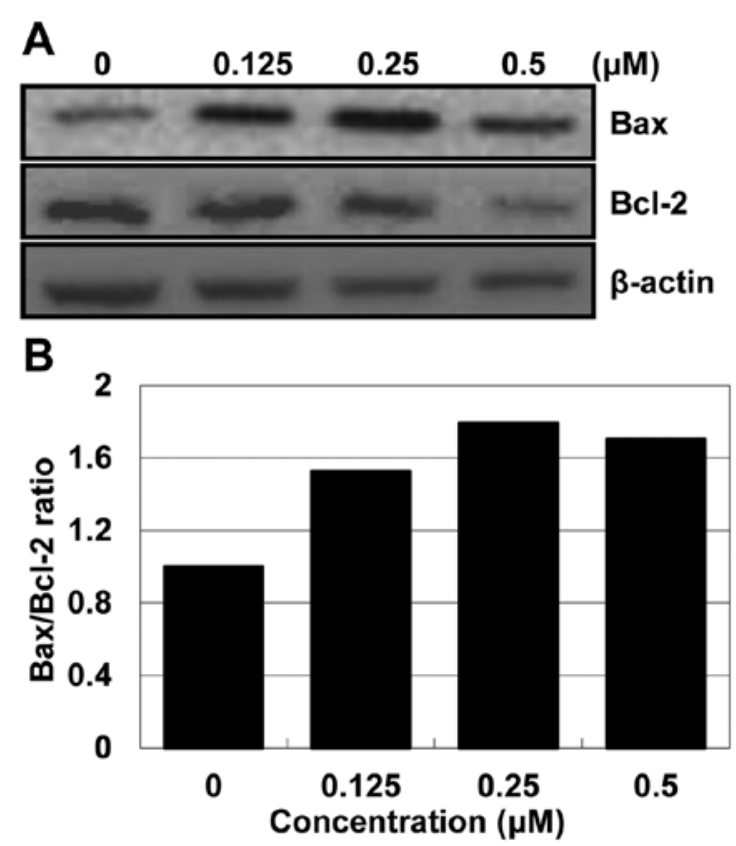

Figure 6. Effects of MHY-449 on the protein expressions of Bax and Bcl-2 in HCT116 cells. (A) HCT116 cells were treated with variable concentrations of MHY-449 for $24 \mathrm{~h}$ and total cell lysates were prepared and immunoblotted. The membranes were detected with antibodies against Bax and Bcl-2 and ECL detection. Representative results from three independent experiments are shown. Actin was used as a loading control. (B) Bax/Bcl-2 ratio was presented in the bar graphs.

related apoptosis-inducing ligand (TRAIL), DR4, and DR5 were not changed after MHY-449 treatment.

MHY-449 increases caspase activity in HCT116 cells. Significant activation of pro-caspase- 3 and -9 were observed and there was little change in pro-caspase-8 (Fig. 5A). Polypeptide degradation, including poly(ADP-ribose) polymerase (PARP), was examined to see the possible involvement of apoptosis-associated protease during the growth inhibition of the colon cancer cells. PARP cleavage was evident by the appearance of the p85 PARP cleavage fragment and clearly observed in the $0.25 \mu \mathrm{M}$ and $0.5 \mu \mathrm{M}$ of MHY-449 treatment. In an attempt to further characterize the mechanisms of apoptosis induced by MHY-449, the activities of caspase $-3,-8$ and -9 were determined by colorimetric assay. The activities of caspase-3, -8 and -9 were increased with the treatment of MHY-449 in concentration-dependent manner (Fig. 5B). Therefore, these results suggested that MHY-449 induce caspase-dependent apoptosis in HCT116 cells.

MHY-449 modulates the expression levels of apopotosisrelated proteins in HCT116 cells. To determine whether the expression levels of apoptosis-related proteins were modulated by MHY-449, western blot analysis was performed. The expression level of Bcl-2 protein was markedly downregulated, while Bax was upregulated in a concentration-dependent manner (Fig. 6A). The ratio between Bcl-2 and Bax has been suggested as a primary event in determining the susceptibility to apoptosis (17). These data suggest that MHY-449 induces apoptosis by the alteration in expression ratio of $\mathrm{Bax} / \mathrm{Bcl}-2$ protein (Fig. $6 \mathrm{~B}$ ). 


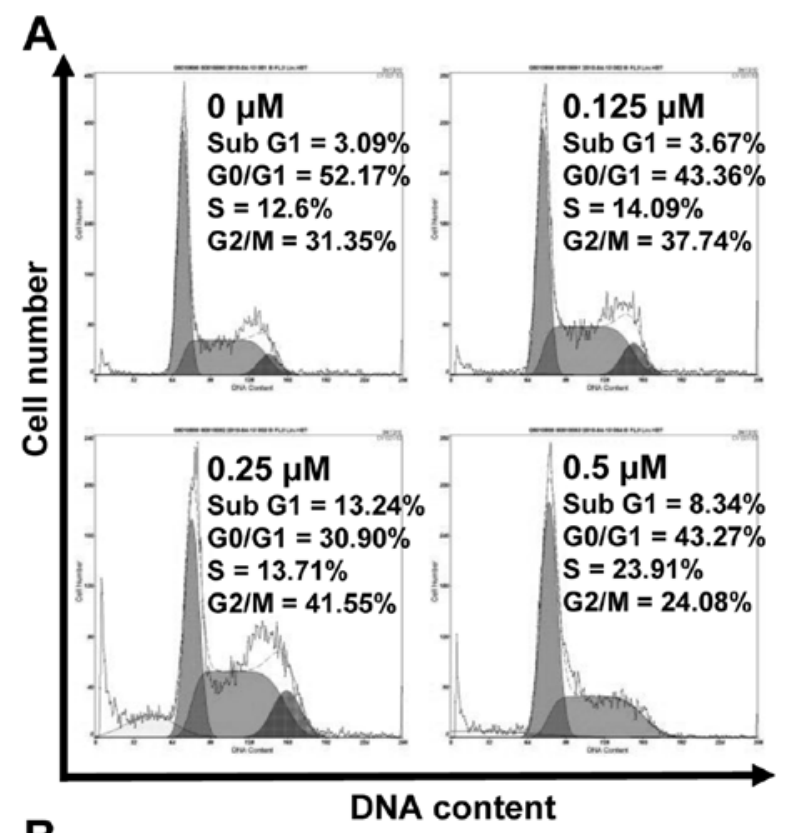

B

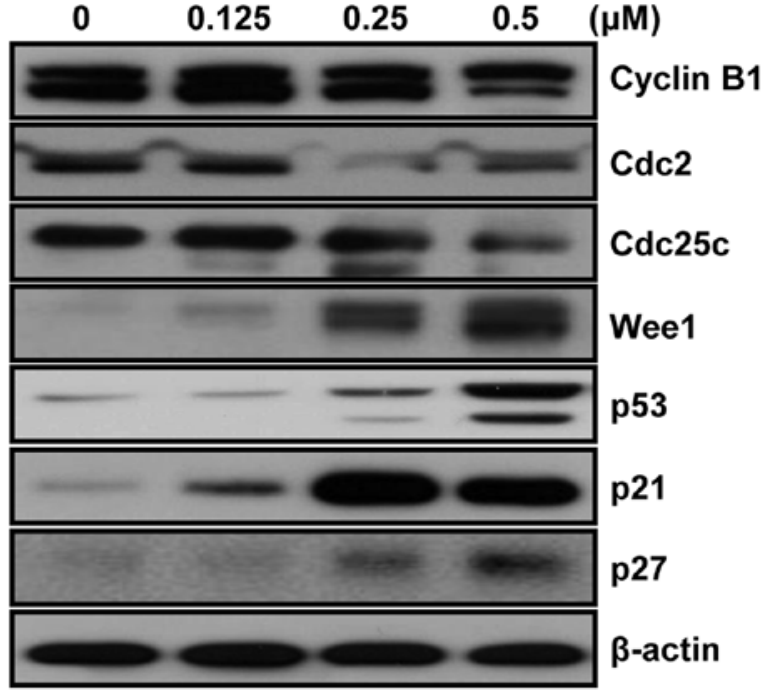

Figure 7. Effects of MHY-449 on the cell cycle and the levels of cell cycle regulatory proteins. (A) Exponentially growing cells at $60-70 \%$ confluence were treated for $24 \mathrm{~h}$ with the indicated concentrations of MHY-449. The percentages of cells in sub-G1, G0/G1, S or G2/M phases of cell cycle are indicated within each histogram. (B) To detect the protein levels of cell cycle regulators, the cells were treated with indicated concentrations of MHY-449 for $24 \mathrm{~h}$, collected, lysed and then cellular proteins were separated and immunoblotted. The membranes were probed with indicated antibodies and ECL detection. Representative results from three independent experiments are shown. Actin was used as a loading control.

MHY-449 modulates cell cycle in HCT116 cells. To investigate whether MHY-449 has an effect on the cell cycle, HCT116 cells were treated with various concentrations of MHY-449 for $24 \mathrm{~h}$ and analyzed with flow cytometry. As shown in Fig. 7A, the cells treated with MHY-449 were remarkably arrested in the $\mathrm{G} 2 / \mathrm{M}$ phase and increased the proportions of sub-G1 phase cells, both in a concentration-dependent manner. A total $41.55 \%$ of cells cultured with $0.25 \mu \mathrm{M}$ MHY-449 were in $\mathrm{G} 2 / \mathrm{M}$ phase, compared to $31.35 \%$ of control in $\mathrm{G} 2 / \mathrm{M}$ phase. In addition, sub-G1 populations were increased from $3.09 \%$ in control to $13.24 \%$ in cells treated with $0.25 \mu \mathrm{M}$ MHY-449. These results suggest that MHY-449 retard the growth of HCT116 cells by arresting cell-cycle progression and apoptosis induction.

MHY-449 modulated cell cycle regulatory proteins in HCT116 cells. The western blot analysis was conducted to further characterize the molecular mechanisms whereby MHY-449 inhibit cell growth and modulate the expression of cell cycle regulating proteins. As shown in Fig. 7B, the intracellular protein levels of $\mathrm{G} 2 / \mathrm{M}$ phase of cell cycle, such as cyclin B1, Cdc2 and Cdc25c were decreased and Wee1 was increased in HCT116 cells by MHY-449 treatment in a concentration-dependent manner. The induction of p2 $1^{\text {WAFI/CIPI }}$ causes subsequent arrest in the $\mathrm{G} 0 / \mathrm{G} 1$ or $\mathrm{G} 2 / \mathrm{M}$ phase of the cell cycle by binding of the cyclin-CDK complex. The protein levels of $\mathrm{p} 21^{\text {WAFI/CIPI }}$ and $\mathrm{p} 27^{K I P}$ were increased in HCT116 cells by MHY-449 treatment in a concentrationdependent manner, and the protein level of p53 was also increased. These results suggest that the significant change in the level of p53 by MHY-449 in HCT116 cells leads to the increase in $\mathrm{p} 21^{\text {WAFI/CIP }}$. Therefore, the induction of $\mathrm{p} 21^{\text {WAFI/CIPI }}$ in HCT116 cells is assumed to be p53-dependent.

\section{Discussion}

This study was conducted to investigate the effects of MHY-449 on HCT116 human colon cancer cells. MHY-449 induced apoptosis and the cell cycle arrest in HCT116 human colon cancer cells. The diastereoisomeric compound, MHY-449 and MHY-450, showed concentration-dependent cytotoxicity on HCT116 cells and MHY-449 exhibited more potent cytotoxicity than MHY-450. Treatment of HCT116 cells with MHY-449 resulted in growth inhibition in a concentration-dependent manner. MHY-449 also resulted in anti-proliferation in a time-dependent manner. Moreover, MHY-449 treatment showed modulation of the cell cycle and induction of apoptosis in HCT116 cells.

The treatment of MHY-449 induced apoptosis as demonstrated by the formation of apoptotic bodies and DNA fragmentation. Apoptosis (programmed cell death), is an important process required for homeostasis $(12,18)$. Apoptosis occurs through two broad pathways: the intrinsic pathway (the mitochondrial pathway) and extrinsic pathway (the death receptor pathway) (19). Death receptors and caspases are key players in the extrinsic pathway, whereas the Bcl-2 family which consists of more than 20 members of pro-apoptotic proteins (including Bax, Bak, Bok, Bad and Bid), and anti-apoptotic proteins (including Bcl-2, Bcl-XL, Mcl-1 and Bfl-1/A1) $(20,21)$ are key players in the intrinsic pathway.

Treatment of HCT116 cells with MHY-449 resulted in increase in expressions of Fas and FasL in a concentrationdependent manner. The activation of initiator caspase- 8 and caspase-9 and downstream effector caspase-3, in response to MHY-449 treatment and cleavage of PARP in HCT116 cells were also observed. The ratio between Bcl-2 and Bax has been suggested as a primary event in determining the susceptibility to apoptosis through maintaining the integrity of the mitochondria and inhibiting the activation of caspase cascade (17). In this study, MHY-449 treatment resulted in a significant increase in pro-apoptotic protein Bax and a 
decrease in anti-apoptotic protein Bcl-2, resulting in a shift in $\mathrm{Bax} / \mathrm{Bcl}-2$ ratio in favor of apoptosis.

Different classes of cyclins and their cyclin-dependent kinase (CDK) control cell cycle progression. G2/M transition provides an effective checkpoint in cell cycle progression, which is regulated by cyclin $\mathrm{B} 1, \mathrm{Cdc} 2$ and $\mathrm{Cdc} 25 \mathrm{C}$ (22). In this study, flow cytometric analysis revealed that treatment of HCT116 cells with MHY-449 resulted in the arrest of cells in G2/M phase and it seems to be associated with a decrease in the protein levels of cyclin B1, Cdc2 and Cdc25C.

Uncontrolled cell proliferation is the hallmark of cancer, and tumor cells have typically acquired damage to gene that directly regulates their cell cycles. Eukaryotic cell cycle checkpoints involve the regulation of sequential formation, activation and subsequent inactivation of CDKs, the activation of which is dependent upon an association with cyclins $(23,24)$. The G2/M transition in the cell cycle plays a pivotal role at the entry into mitosis, the complex of which is formed by the association of Cdc2 and cyclin B1 (25). Binding to cyclin B and phosphorylation at threonine 161 by $\mathrm{CDK}$ activating kinase (CAK) are required to activate $\mathrm{Cdc} 2$ during $\mathrm{G} 2$ and the $\mathrm{Cdc} 2 /$ cyclin $\mathrm{B}$ complex is kept inactive by phosphorylation in tyrosine 15 (Tyr 15) and threonine 14 of $\mathrm{Cdc} 2$ by the kinases Weel and Myt1, respectively $(26,27)$. CDK-cyclin complexes are regulated by two families of CDK inhibitors (CKIs), the CIP/KIP family (p21 $1^{\text {WAF/CIP }}, \mathrm{p} 27^{K I P 1}$, and $\mathrm{p} 57^{K I P 2}$ ) and INK4 family (p15 $5^{I N K 4 b}, \mathrm{p} 16^{I N K 4 a}, \mathrm{p} 18^{I N K 4 c \text {, }}$ and $\mathrm{p} 19^{I N K 4 d}$ ) (28). Members of CIP/KIP family, such as $\mathrm{p} 21^{\text {WAIF/CIPI }}$, bind to CDK/cyclin complexes and prevent kinase activation, subsequently regulating G2/M-phase transition $(29,30)$ and upregulation in response to the inhibition of cell growth.

p2 $1^{\text {WAFI/CIPI }}$ is commonly associated with the G1 check point and $\mathrm{G} 2 / \mathrm{M}$ phase, and its association with inhibiting the expression of the $\mathrm{Cdc} 2 /$ cyclin $\mathrm{B} 1$ complex has been also reported (29,31). p21 $1^{\text {WAFI/CIPI }}$ transcription can be regulated through either p53-dependent (32) or p53-independent pathways (33). In the present study, $\mathrm{p} 21^{\text {WAFI/CIPI }}$ was increased by MHY-449 in HCT116 cells, along with significant increase in the protein levels of $\mathrm{p} 53$. These results suggest that MHY-449 upregulates p21 ${ }^{\text {WAFI/CIPI }}$ expression and thereby leading to G2/M-phase arrest through p53-dependent pathway.

p $27^{K I P I}$ exerts tumor suppressing function through inhibitory interactions with the cyclin/CDK complexes, and downregulation of $\mathrm{p} 27^{K I P 1}$ protein is often correlated with poor prognosis in several types of human cancers. Our result showed that p $27^{K I P I}$ was increased by the treatment of MHY-449. However, p2 $7^{K I P I}$ possess oncogenic function as well, and in many cases it is known to be cyclin/CDK independent and attributed to its cytoplasmic localization (34).

In summary, MHY-449 suppressed growth and proliferation of HCT116 cells in a concentration- and time-dependent manner, respectively, by causing G2/M cell cycle arrest and induction of apoptosis. Taken together, these results suggest that novel compound MHY-449 may be useful in the chemoprevention and/or treatment of colon cancer.

\section{Acknowledgements}

This study was supported by National Research Foundation of Korea (NRF) grant funded by the Korea government (MOST) (no. 20090083538). We thank Aging Tissue Bank for providing research information.

\section{References}

1. Cooper K, Squires H, Carrol C, Papaioannou D, Booth A, Logan RF, Maguire C, Hind D and Tappenden P: Chemoprevention of colorectal cancer: systematic review and economic evaluation. Health Technol Assess 14: 1-206, 2010.

2. Jemal A, Siegel R, Xu J and Ward E: Cancer statistics, 2010. CA Cancer J Clin 60: 277-300, 2010.

3. National Cancer Information Center: Cancer incidence. Goyang. http://www.cancer.go.kr/ncic/cics. Accessed Dec 29, 2011.

4. Kelly C and Cassidy J: Chemotherapy in metastatic colorectal cancer. Surg Oncol 16: 65-70, 2007.

5. Yang SY, Sales KM, Fuller BF, Seifalian AM and Winslet MC: Apoptosis and colorectal cancer: implications for therapy. Trends Mol Med 15: 225-233, 2009.

6. Peter ME: The flip side of FLIP. Biochem J 382: E1-E3, 2004.

7. Ashkenazi A: Targeting the extrinsic apoptosis pathway in cancer. Cytokine Growth Factor Rev 19: 325-331, 2008.

8. Inada H, Izawa I, Nishizawa M, Fujita E, Kiyono T, Takahashi T, Momoi $\mathrm{T}$ and Inagaki I: Keratin attenuates tumor necrosis factor-induced cytotoxicity through association with TRADD. J Cell Biol 155: 415-426, 2001.

9. Cory S and Adams JM: The Bcl2 family: regulators of the cellular life-or-death switch. Nat Rev Cancer 2: 647-656, 2002.

10. Kuwana T, Mackey MR, Perkins G, Ellisman MH, Latterich M, Schneiter R, Green DR and Newmeyer DD: Bid, Bax, and lipids cooperate to form supramolecular openings in the outer mitochondrial membrane. Cell 111: 331-342, 2002.

11. Oliver L and Vallette FM: The role of caspases in cell death and differentiation. Drug Resist Updat 8: 163-170, 2005.

12. Iannolo G, Conticello C, Memeo L and De Maria R: Apoptosis in normal and cancer stem cells. Crit Rev Oncol Hematol 66: 42-51, 2008.

13. Kupchan SM, Streelman DR and Sneden AT: Psorospermin, a new antileukemic xanthone from Psorospermum febrifugum. J Nat Prod 43: 296-301, 1980.

14. Cassady JM, Baird WM and Chang CJ: Natural products as a source of potential cancer chemotherapeutic and chemopreventive agents. J Nat Prod 53: 23-41, 1990.

15. Dorr RT, Liddil JD, Von Hoff DD, Soble M and Osborne CK: Antitumor activity and murine pharmacokinetics of parenteral acronycine. Cancer Res 49: 340-344, 1989.

16. Kang JA, Yang Z, Lee JY, De U, Kim TH, Park JY, Lee HJ, Park YJ, Chu P, Kim KS, Jeong LS and Moon HR. Design, synthesis and anticancer activity of novel dihydrobenzofuro[4,5b] $[1,8]$ naphthyridin-6-one derivatives. Bioorg Med Chem Lett 21: 5730-5734, 2011.

17. Harris MH and Thompson CB: The role of the Bcl-2 family in the regulation of outer mitochondrial membrane permeability. Cell Death Differ 7: 1182-1191, 2000.

18. Call JA, Eckhardt SG and Camidge DR: Targeted manipulation of apoptosis in cancer treatment. Lancet Oncol 9: 1002-1011, 2008.

19. Lorenzo HK and Susin SA: Therapeutic potential of AIF-mediated caspase-independent programmed cell death. Drug Resist Updat 10: 235-255, 2007.

20. Antonsson B and Martinou JC: The Bcl-2 protein family. Exp Cell Res 256: 50-57, 2000.

21. Guo B, Godzik A and Reed JC: Bcl-G, a novel pro-apoptotic member of the Bcl-2 family. J Biol Chem 276: 2780-2785, 2001.

22. Molinari M: Cell cycle checkpoints and their inactivation in human cancer. Cell Prolif 33: 261-274, 2000.

23. Sherr CJ: Cancer cell cycles. Science 274: 1672-1677, 1996.

24. Murray AW: Recycling the cell cycle: cyclins revisited. Cell 116: 221-234, 2004.

25. Sancar A, Lindsey-Boltz LA, Unsal-Kaçmaz K and Linn S: Molecular mechanisms of mammalian DNA repair and the DNA damage checkpoints. Annu Rev Biochem 73: 39-85, 2004.

26. Taylor WR and Stark GR: Regulation of the G2/M transition by p53. Oncogene 20: 1803-1815, 2001.

27. Le Gac G, Estève PO, Ferec $\mathrm{C}$ and Pradhan S: DNA damageinduced down-regulation of human $\mathrm{Cdc} 25 \mathrm{C}$ and $\mathrm{Cdc} 2$ is mediated by cooperation between p53 and maintenance DNA (cytosine-5) methyltransferase 1. J Biol Chem 281: 24161-24170, 2006. 
28. Malumbres $\mathrm{M}$ and Barbacid M: Cell cycle, CDKs and cancer: a changing paradigm. Nat Rev Cancer 9: 153-166, 2009.

29. Baus F, Gire V, Fisher D, Piette J and Dulić V: Permanent cell cycle exit in G2 phase after DNA damage in normal human fibroblasts. EMBO J 22: 3992-4002, 2003.

30. Hsu YL, Kuo PL, Lin LT and Lin CC: Asiatic acid, a triterpene, induces apoptosis and cell cycle arrest through activation of extracellular signal-regulated kinase and p38 mitogenactivated protein kinase pathways in human breast cancer cells. J Pharmacol Exp Ther 313: 333-344, 2005.

31. Niculescu AB III, Chen X, Smeets M, Hengst L, Prives C and Reed SI: Effects of p21(Cip/Waf1) at both the G1/S and the $\mathrm{G} 2 / \mathrm{M}$ cell cycle transition: $\mathrm{pRb}$ is a critical determinant in blocking DNA replication and in preventing endoreduplication. Mol Cell Biol 18: 629-643, 1998.
32. El-Deiry WS, Tokino T, Velculescu VE, Levy DB, Parsons R, Trent JM, Lin D, Mercer WE, Kinzler KW and Vogelstein B: WAF1, a potential mediator of p53 tumor suppression. Cell 75: 817-825, 1993.

33. Gartel AL and Tyner AL: Transcriptional regulation of the p21(WAF1/CIP1) gene. Exp Cell Res 246: 280-289, 1999.

34. Lee J and Kim SS: The function of p27 KIP1 during tumor development. Exp Mol Med 41: 765-771, 2009. 